\title{
ОЦЕНКА ЭФФЕКТИВНОСТИ ДЕЯТЕЛЬНОСТИ В ОТРАСЛИ ХИМИЧЕСКОЙ ПРОМЫШЛЕННОСТИ САМАРСКОЙ ОБЛАСТИ НА ПРИМЕРЕ ПАО «ТОЛЬЯТТИАЗОТ»
}

\author{
(c) 2020 Кучерявенко Дмитрий Михайлович \\ кандидат экономических наук, доцент, кафедра «Экономика и управление организацией» \\ Самарский государственный технический университет (СамГТУ), Россия, Самара
}

В данной статье рассматривается химическая промышленность Самарской области, которая играет важную роль в жизни не только России, но и стран, находящихся за ее пределами. На примере одного из лидирующих предприятий в мировом масштабе в сфере выпуска минеральных удобрений и химической продукции - ПАО «Тольяттиазот». Компания является поставщиком более десяти стран мира, расположенных на пяти континентах. Предприятие положительно влияет на жизнь и развитие региона, а также способствует улучшению социально-экономического климата. Это дает возможность для решения различного рода проблем, связанных с трудовыми ресурсами города. Представлены приоритетные сферы, в которых компания планирует развиваться. Это говорит об актуальности выбранного исследования в рамках Самарского региона. Предметом исследования выступила отрасль химической промышленности. Объектом стала деятельность компании ПАО «Тольяттиазот». Был проведен анализ и внутренней и внешней среды компании с помощью следующих методов: SWOT-анализ и матрица Р. Дункана. Исследование носит теоретический и практический характер.

Было выяснено, что предприятие имеет большой запас прочности и внушительное количество сильных сторон, оно активно развивается и щедро инвестирует в новые разработки и строительство производств. Было доказано, что ПАО «Тольяттиазот» - это развивающееся и конкурентоспособное предприятие, которое пользуется популярностью как на внутреннем, так и на международном рынке. Было выяснено, внешняя среда компании сложная и стабильная, потому как факторы среды не меняются неожиданно, их можно предусмотреть, но таких факторов достаточно много. Это означает, что источники предкризисных сигналов достаточно стабильны. Было видно, что наибольшее воздействие на деятельность предприятия извне оказывают технологические, экономические и политические факторы. Было выявлено, что предприятие имеет высокое качество продукции, которая востребована на внутреннем и международном рынке, имеет налаженную систему финансовых и экономических связей, имеет программы обучения и повышения квалификации персонала компании.

Ключевые слова: химическая промышленность, оценка эффективности, анализ среды, ликвидность активов, финансовые показатели, платёжеспособность, предприятие, финансовая устойчивость.

Территориальные различия природных условий и ресурсов, а также историческое наследие создают предпосылки развития каждого региона по-разному. Эти различия определяют формирование историко-географических областей, а в пределах стран - экономических районов, и являются основой для выделения административных единиц [8]. Ограниченность имеющихся ресурсов в регионе, их взаимозаменяемость, в первую очередь ресурсов общего назначения, объясняют необходимость взаимосвязанного сбалансированного развития регионов для увеличения производства необходимых обществу товаров и услуг, а также повышения уровня жиз- ни граждан [7].

Самарская область является пятым по площади регионом Поволжья. Химическая и нефтехимическая промышленность является базовой отраслью экономики Самарской области, она занимает второе место по объему годового производства в отраслевой структуре промышленности области. Предприятия комплекса выпускают 30\% российского производства синтетического аммиака и синтетических каучуков, 13\% - метанола, $6 \%$ - синтетических смол, пластических масс и химических средств защиты растений [1].

Предприятия, работающие в данной отрасли, размещены практически во всех городах об- 
ласти. Наличие этого мощного комплекса, безусловно, стимулирует экономическое развитие региона и способствует улучшению социальноэкономического климата региона. Расширение существующих производств и создание новых, дает возможность решить проблему занятости населения, в частности, в тех городах, где эти предприятия являются градообразующими: в Тольятти, Новокуйбышевске, Чапаевске [5].

Одним из крупнейших предприятий химической промышленности в России и за рубежом является Публичное акционерное общество «Тольяттиазот», расположенное в г. Тольятти. Предприятие было основано в 1979 г.

Основной деятельностью является выпуск минеральных удобрений и химической продукции. Включает в себя 7 агрегатов по производству аммиака и 2 агрегата карбамида, расположенных на более чем 300 га производственной площадки. Компания является публичным акционерным обществом и имеет листинг акций на Московской бирже [4].

С самого своего основания «Тольяттиазот» играет значимую роль в развитии химической отрасли страны, и в обеспечении благополучия всей Самарской области. Основными продуктами производства являются: аммиак, минеральные удобрения, карбамид, КФК, аммиачная вода, а также другая химическая продукция.

Заказчики расположены, помимо России, в десятках зарубежных стран. Мощности компании позволяют обеспечить около $25 \%$ спроса на российском рынке и $12 \%$ объема мирового экспорта аммиака. Бесперебойность поставок гарантирует развитая инфраструктура: помимо собственного железнодорожного парка, имеется доступ к уникальному аммиакопроводу «Тольятти-Одесса» протяженностью более 2000 км. [4]

Модернизация, технологии, экология, человеческий капитал - это приоритеты развития «Тольяттиазот». Постоянное движение позволило стать лидером в своей отрасли в России и за ее пределами.

Рассмотрим подробнее среду, в которой работает и развивается предприятие. Проведем анализ внешней и внутренней среды с помощью метода SWOT-анализ:

Во внутренней среде рассмотрим сильные и слабые стороны предприятия, а во внешней среде проанализируем возможности компании и вероятность наступления различных угроз (Таблица).

Итак, предприятие имеет большой запас прочности и внушительное количество сильных сторон, оно активно развивается и щедро инвестирует в новые разработки и строительство производств. Это характерная черта всех предприятий химической отрасли: для расширения производства или создания нового продукта компании необходимо не просто купить станок, а организовать новый завод, целое производственное предприятие. Отсюда и такие ежегодные суммы вложений - 12,2 млрд. руб. в 2019 году. Однако существует большое количество внешних угроз и чтобы их перекрыть, предпри-

\begin{tabular}{|c|c|}
\hline$S$ & W \\
\hline $\begin{array}{l}\text { - Высокое качество продукции, востребованной на } \\
\text { внутреннем и международном рынках } \\
\text { - Налаженная система финансовых и экономиче- } \\
\text { ских связей; } \\
\text { - Устоявшееся место в отрасли на территории Рос- } \\
\text { сии; } \\
\text { - Наличие программ обучения и повышения квали- } \\
\text { фикации персонала компании; } \\
\text { - Низкая степень текучести персонала } \\
\text { Отлаженная производственная линия } \\
\text { - Значительные производственные мощности; } \\
\text { - Регулярное обновление производственных мощ- } \\
\text { ностей и введение новых производственных объек- } \\
\text { тов. }\end{array}$ & $\begin{array}{l}\text { - Высокая стоимость производимой продукции из- } \\
\text { за отсутствия экономии на масштабе (локальность } \\
\text { производства); } \\
\text { - Отсутствие кооперации с ведущими предприятия- } \\
\text { ми отрасли (Например, как «АВТОВАЗ»); } \\
\text { - Преобладание не самого современного оборудо- } \\
\text { вания } \\
\text { - Отсутствие возможности увеличения объемов } \\
\text { производимой продукции в краткосрочном и средне- } \\
\text { срочном периоде. }\end{array}$ \\
\hline $\mathrm{O}$ & $\mathrm{T}$ \\
\hline $\begin{array}{l}\text { - Предложения о международном альянсе с крупны- } \\
\text { ми предприятиями; } \\
\text { - Привлечение инвестиций от российских и зару- } \\
\text { бежных компаний; } \\
\text { - Курсовые разницы; } \\
\text { - Появление новых материалов и разработок. }\end{array}$ & $\begin{array}{l}\text { - Возможность введения экономических санкций, } \\
\text { квот ввоза и вывоза продукции; } \\
\text { - Вероятность изменения валютных курсов; } \\
\text { - Сокращение контрактов и субсидий от государ- } \\
\text { ства. }\end{array}$ \\
\hline
\end{tabular}


ятию нужно приложить немало усилий и выработать качественную и эффективную стратегию деятельности, все предпосылки для реализации которой имеются в возможностях компании. В целом, ПАО «Тольяттиазот» - это развивающееся и конкурентоспособное предприятие, которое пользуется популярностью как на внутреннем, так и на международном рынке.

Так как факторы внешней среды оказывают существенное влияние на деятельность предприятия «Тольяттиазот», проведем анализ при помощи матрицы Р. Дункана, который позволит оценить степень неопределенности внешней среды.

Факторы внешней среды «Тольяттиазот» изменяются, так как осуществляются новые разработки и изменяется экономическая обстановка, но они изменяются медленно в силу специфики химической отрасли: продукция имеет постоянный спрос, производство невозможно перестроить быстро.

У компании много внешних факторов: так как она осуществляет сложную производственную деятельность на разбросанной территории, к тому же, предприятие осуществляет активную экспортную деятельность, которая предполагает ряд факторов, связанных с международной политикой, законодательством и налогообложением [6].

Из чего можно сделать вывод о том, что внешняя среда компании сложная и стабильная, потому как факторы среды не меняются неожиданно, их можно предусмотреть, но этих факторов достаточно много. Это означает, что источники предкризисных сигналов достаточ- но стабильны. Таким образом, внешняя среда деятельности компании «Тольяттиазот» имеет среднюю неопределенность.

Наибольшее воздействие на деятельность предприятия извне оказывают технологические, экономические и политические факторы [10].

Для того, чтобы нивелировать или в некоторой степени снизить их влияние, предприятию необходимо проводить следующие мероприятия [2]:

- Развивать уровень качества производимой продукции;

- Находить новые рынки сбыта;

- Развивать направления для повышения добавленной стоимости продукта;

- Заключать долгосрочные договора и ориентировать на долгосрочное сотрудничество;

- Анализировать рынок на предмет изменения обстановки.

Подводя итог, можно сказать, что ПАО «Тольяттиазот» - одна из ведущих российских химических компаний, входит в число крупнейших производителей азотных удобрений. Активная инвестиционная политика обеспечивает быстрый и эффективный рост и устойчивое развитие. Внешняя среда компании достаточно сложная и стабильная, имеет среднюю неопределенность. Факторы внешней среды «Тольяттиазот» изменяются, но довольно медленно в силу специфики химической отрасли. Предприятие имеет большой запас прочности и внушительное количество сильных сторон, оно активно развивается и работает над инвестиционной привлекательностью [12].

\section{Библиографический список}

1. Абдурахманова Л.С. Продовольственная безопасность региона: сущность, угрозы, факторы, ее определяющие // Региональные проблемы преобразования экономики. 2016. № 3. С. 20-25.

2. Ахмедуев А.Ш., Меджидо З. У. Теоретические аспекты о сущности и роли территорий с особым экономическим статусом в обеспечении пространственного развития регионов России. Вопросы региональной экономики. 2019. № 40(3). С. 3-7.

3. Зубаревич Н. В. Стратегия пространственного развития после кризиса: от больших проектов к институциональной модернизации // Журнал новой экономической ассоциации. 2015. № 2 (26). С. 226-230.

4. Официальный сайт ПАО «Тольяттиазот». URL: https://www.toaz.ru (дата обращения: 19.12.2020)

5. Официальный сайт Самарской области. URL: http://samarastat.gks.ru (дата обращения: 19.12.2020)

6. Региональная экономика. Основы теории и методы исследования: учебное пособие / В.В.Курнышев, В. Г. Глушкова. // М.: КНОРУС. 2010. С. 256.

7. Региональная экономика и управление/ Учебник / В. К. Крутиков, Л. А. Косогорова, М. В. Якунина, и др.; Под руководством и редакцией В.К. Крутикова. // Калуга: Изд-во АКФ «Политоп». 2018. С. 864.

8. Региональная экономика. Учебно-методическое пособие. // Калуга: Изд-во «Эйдос». 2015. С. 202. 
9. Рубцов Г.Г., Литвиненко А. Н. Анализ этапов оценки эффективности деятельности органов исполнительной власти субъектов Российской Федерации // Научно-технические ведомости СПбГПУ. Экономические науки. 2018. T. 11, № 5. C. 74-86. DOI: 10.18721/JE.11507

10. Сураева М.О.Развитие компенсационных систем в сфере регулирования трудовых отношений через инструменты менеджмента //Экономика и бизнес: управление экономическими системами.2015. С. 1-13.

11. Сураева М.О.Инновационное развитие предприятий промышленного комплекса // Экономика и управление. № 1(11).2020. С. 66-69.

12. Татаркин А. И. Региональная направленность экономической политики Российской Федерации как института пространственного обустройства территорий // Экономика региона. 2016. Т. 12. № 1. С. 9-27. 